\title{
RESULTS OF IMMUNIZATION BY MEANS OF ACTIVE VIRUS OF HUMAN INFLUENZA ${ }^{1}$
}

\author{
By JOSEPH STOKES, JR., ALICE D. CHENOWETH, ARTHUR D. WALTZ, RALPH \\ G. GLADEN, AND DOROTHY SHAW
}

(From the Department of Pediatrics, School of Medicine, University of Pennsylvania, and the Children's Hospital of Philadelphia, Philadelphia)

(Received for publication December 1, 1936)

The studies reported here deal with the prevention of "influenza" in a group of individuals immunized by means of intramuscular injections of active ${ }^{2}$ human influenza virus in the presence of an oncoming epidemic which occasioned a marked morbidity in the unvaccinated people of the same community.

Shope $(1,2,3,4)$ first reported the successful immunization of hogs against swine influenza by the intramuscular injection of active swine influenza virus; the swine were immunized not only against the mild respiratory disease, "filtrate disease," caused by the virus alone, but also against the severe respiratory disease, true swine influenza, which is caused by the synergistic activity of the swine influenza virus and Hemophilus influenzae suis, an organism indistinguishable morphologically and culturally from the nonindol-producing strains of the human Pfeiffer's bacillus. Smith, Andrewes, and Laidlaw (5, 6, $7,8,9)$ and Francis, Magill and Shope $(10,11$, $12,13,14,15)$ demonstrated that ferrets and mice could be infected by the viruses of swine and human influenza and could be immunized against the severe manifestations of the diseases by the subcutaneous injection of active virus. The human influenza virus was more active in its production of cross-neutralizing properties than was the swine influenza virus which they found might or might not produce such cross-neutralization depending apparently upon the number of exposures. They noted that a ferret recovering from the swine influenza virus became partially or completely immune also to the virus of human

1 These studies were assisted by a grant from the $\mathrm{Bu}$ reau of Animal Industry, United States Department of Agriculture, and by the Lyophile Serum Fund donated by the Board of Managers of the Abington Memorial Hospital.

2 The term "active" is here applied to virus which is capable of producing the disease. influenza and vice versa; the human influenza virus, however, was more active in its production of such a cross-immunity. The immunity in the recovered ferrets remained for approximately three months (8). Neutralizing properties in the sera of ferrets were at a high level following the disease or following active immunization and were still present, but in much reduced amounts, when the animals again became susceptible to the disease (8). The synergistic activity of a virus and a bacterium was not necessary to produce a severe lower respiratory infection in ferrets and mice, although Francis (16) has shown that ferrets harboring pathogenic hemolytic streptococci develop more severe manifestations of lower respiratory infection when influenza virus is injected into the respiratory tract than do the animals in which streptococci are absent. These workers demonstrated that susceptible animals were not infected by injections of active virus except when it was placed directly in the respiratory tract, since in their experiments subcutaneous, intramuscular, intraperitoneal and intravenous injections did not produce the disease.

In view of the successful production of active immunity in lower animals and in view of the prevalence of human influenza due to similar strains of virus in such widely separated places as Australia (17), England, Puerto Rico, New York, Alaska and Philadelphia $(14,18)$, it appeared essential to study the production of active immunity in human beings with a view towards prevention of the epidemic disease.

\section{Neutralization tests}

In September and October of 1935, several members of the hospital staff and a few hospitalized children who showed only small amounts of neutralizing substances in their sera against the human and swine viruses (PR-8 of Francis and 
S-15 of Shope) were injected intramuscularly with both agents in an active state. An increase in the amount of neutralizing substances to the homologous virus in the sera of a number of the

HUMAN VIRUS PR-8

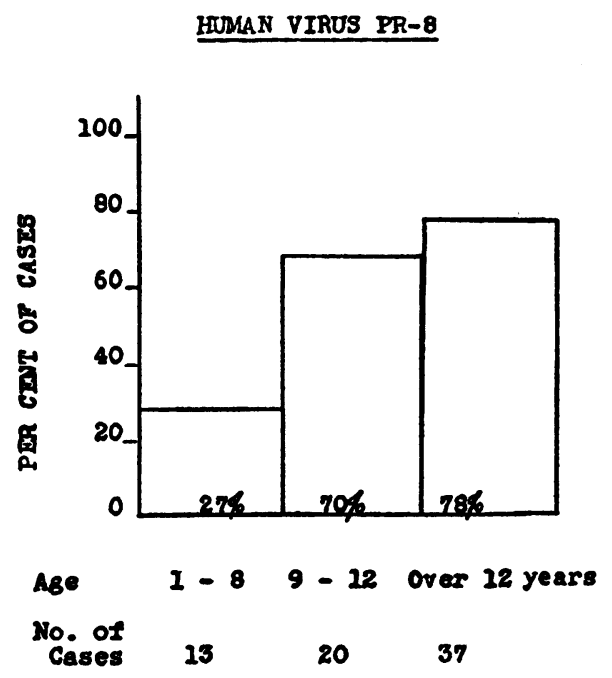

which resembled influenza clinically appeared rather suddenly in and around Philadelphia. Shortly following the advent of the first few cases, immunization with the active viruses of

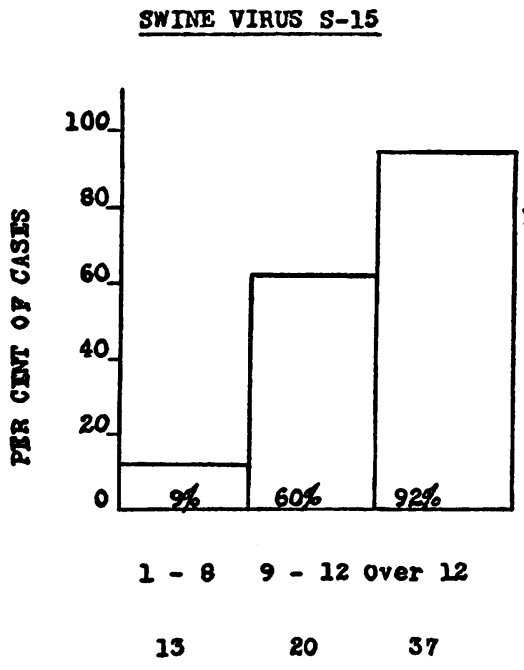

Fig. 1. Virus Neutralizing Substances by Age Groups in Unvaccinated INDIVIDUALS

individuals was noted, results similar to those reported for experiments with the human influenza virus conducted simultaneously by Francis and Magill (19).

During the fall and early winter of 1935 , sera of a large group of individuals over a wide age range were tested for the presence of neutralizing antibodies against the viruses of human and swine influenza. The results of the tests conform in general to those conducted by the workers already mentioned $(20,21)$, and are shown in Figure 1 . In contrast to the results already reported a few of the sera of the children under twelve years of age showed neutralizing properties against the virus of swine influenza S-15 of Shope. ${ }^{3}$

A large number of the sera included in Figure 1 were obtained from a State Colony ${ }^{4}$ of approximately eight hundred males, men and boys, near Philadelphia, and it was during the studies of them in February, 1936, that an epidemic

8 This finding may have been due to the comparatively close contact of this group of children with a herd of swine.

$4 \mathrm{We}$ are indebted to the Department of Institutions and Agencies of the State of New Jersey, and to Dr. Carroll T. Jones, Superintendent of the Colony, for their cooperation in these studies. human and swine influenza was initiated in the colony.

\section{Preparation of vaccine}

In the preparation of vaccine for the study of active immunization, the viruses ( $\mathrm{S}-15$ of Shope and PR-8 of Francis) were grown both upon chick embryo in modified tissue cultures and in mouse lung. During the early part of the winter of 1935 the PR-8 strain grown upon chick embryo failed to give constant lesions in mice. For this reason and as a temporary expedient, a 10 per cent emulsion of infected mouse lung in normal saline solution was used as a vaccine. This emulsion was filtered through a Berkefeld filter, the filtrate was cultured, and intramuscular injections of $0.5 \mathrm{cc} ., 1 \mathrm{cc}$. and $1 \mathrm{cc}$. were given at intervals of one week. Anesthetized mice were inoculated intranasally with the filtrate immediately preceding and following the intramuscular injection, in order to be certain that active virus was present in the vaccine. The Swiss mice used for the vaccine were from a stock colony, free as far as could be determined from viruses infectious for man, including the virus of choriomeningitis described by Armstrong and Lillie (22) and by 
Rivers and Scott (23). There was some loss of virus during filtration, and for this reason, as well as for the better control of possible extraneous viruses, we would have preferred chick embryo media, had the growth of $P R-8$ virus been constant. Experience has shown also that chick embryo tissue is a weak antigen in comparison with the protein of mouse lung. In later studies an alteration of the method of culture on chick embryo insured relatively constant growth of the virus.

\section{CLINICAL STUDY}

The colony had 17 houses amongst which the inmates were about equally divided. There was a common dining hall and a common amusement hall which insured close contacts of all the inmates. Approximately one-third of the inmates of each house was injected, one-half of this number, namely one-sixth, being injected with active swine virus, the other one-sixth with active human virus. ${ }^{5}$ A greater number were given swine vaccine than human vaccine so that in all 110 were injected with human virus and 138 with swine virus; approximately 550 were unvaccinated. Mild local reactions to the vaccine were noted in a few individuals, and in one instance marked localized erythema and tenderness with slight swelling remained for two days at the site of injection. Although those injected were under constant observation, no allergic or generalized reactions were noted. Blood for neutralization tests was collected from the 248 injected individuals before vaccination and again two weeks following the third injection of vaccine. At the same time blood for similar tests was collected from sixty of those not vaccinated. Because the first neutralization tests showed that the undiluted sera of a large part of the colony neutralized both swine and human influenza viruses, further tests were performed with serum diluted as much as $1: 80$. The neutralizing antibodies in collected serum do not change over a considerable period of time at ice-box temperature, and for this reason it was possible to examine the sera taken

5 Shope demonstrated in his experiments on influenza in swine that if as much as one-half of a herd of swine was actively immunized, an epidemic of the disease would not spread readily through the herd; whereas when only one-third of the herd was immunized a more rapid spread of the disease occurred. before and after the injections of vaccine at the same time against the same virus suspension. It was found that the dilution of sera with physiological salt solution had a deleterious effect on the viruses, and after trial of several diluents, nutrient broth was selected as the most satisfactory. Healthy white mice ${ }^{6}$ were inoculated under ether anesthesia with 10 per cent saline suspensions of either the swine or human strain of virus. The mice were killed when moribund or at the end of the sixth day, and their lungs were removed aseptically and stored in 50 per cent glycerine. A weighed 2 per cent saline suspension of these infected lungs was made and centrifuged at about 1200 r.p.m. for two minutes. The sera were diluted with nutrient broth $1: 10$ and $1: 40$ for testing against the human strain, and $1: 20$ and $1: 80$ for the testing against the swine strain. The diluted sera were mixed with equivalents of a 2 per cent suspension of infected lung and placed in the ice box at 3 to $4^{\circ} \mathrm{C}$. overnight. Each mixture was inoculated intranasally into three mice under ether anesthesia. At the end of the sixth day the mice still living were killed and their lungs examined. The neutralizing effect of a serum of unknown potency was determined by a comparison of the extent of lung lesions in mice receiving the mixture of the virus and the serum in question, with the lesions in the mice receiving the mixture of nutrient broth and virus. The severity of the lung lesions was tabulated as 1,2 , 3 , and $4+$. $^{7}$

Table I shows a summary of the results of the neutralization tests in the three groups of individuals in the colony. Due to a number of factors, such as contamination and the necessity for repetition, it was not possible to include in this table all of the sera collected. It is to be noted that a significant increase in the amount of neutralizing antibodies occurred only in the indi-

\footnotetext{
- We are indebted to Sharpe and Dohme Company for the majority of mice used in this study.

7 " $1+"$ Influenzal pneumonia involving up to $1 / 4$ of lung at postmortem.

" $2+$ " Influenzal pneumonia involving from $1 / 4$ to $1 / 2$ of lung at postmortem.

“ $3+$ " Influenzal pneumonia involving from $1 / 2$ to $3 / 4$ of lung at postmortem.

" $4+$ " Influenzal pneumonia involving from $3 / 4$ to all of lung at postmortem.
} 
viduals injected with the human strain of virus; even in this group only 31 per cent, as calculated, showed such an increase. In the summary of a previous report (24) it was stated that "both the human and the swine vaccinated groups showed an increase in neutralizing substances to their homologous viruses, and to a lesser extent to their heterologous viruses." In the repetition of the tests the use of nutrient broth in place of physiological salt solution as a diluent altered the findings as noted in Table I.

TABLE I

Summary of neutralization tests

\begin{tabular}{|c|c|c|c|c|c|c|c|}
\hline \multirow{2}{*}{ Group } & \multirow{2}{*}{$\begin{array}{c}\text { Total } \\
\text { num- } \\
\text { ber of } \\
\text { sera } \\
\text { tested }\end{array}$} & \multicolumn{2}{|c|}{ Increase } & \multicolumn{2}{|c|}{ No increase } & \multicolumn{2}{|c|}{ Decrease } \\
\hline & & $\underset{\text { ber }}{\text { Num- }}$ & $\begin{array}{l}\text { Per } \\
\text { cent }\end{array}$ & $\underset{\text { ber }}{\text { Num- }}$ & $\begin{array}{l}\text { Per } \\
\text { cent }\end{array}$ & $\underset{\text { ber }}{\text { Num- }}$ & $\begin{array}{l}\text { Per } \\
\text { cent }\end{array}$ \\
\hline
\end{tabular}

AGAINST S-15 SWINE INFLUENZA VIRUS

\begin{tabular}{l|r|r|r|r|r|l|l}
\hline Unvaccinated..... & 43 & 8 & 18.6 & 35 & 81.4 & 0 & 0 \\
S-15 vaccinated... & 107 & 21 & 19.6 & 83 & 77.6 & 3 & 2.8 \\
PR-8 vaccinated.. & 86 & 14 & 16.2 & 72 & 83.8 & 0 & 0 \\
\hline
\end{tabular}

AGAINST PR-8 HUMAN INFLUENZA VIRUS

\begin{tabular}{l|r|r|r|l|l|l|l}
\hline Unvaccinated..... & 45 & 4 & 8.8 & 38 & 84.4 & 3 & 6.7 \\
S-15 vaccinated... & 112 & 10 & 8.9 & 98 & 87.5 & 4 & 3.5 \\
PR-8 vaccinated.. & 84 & 25 & 31.0 & 58 & 69 & 0 & 0 \\
\hline
\end{tabular}

\section{RESULTS}

The epidemic covered a period of approximately two months, beginning in the latter half of February, with the largest number of cases occurring during the fifth week. Although a few cases of the disease occurred previous to vaccination, during the period of the study approximately 25 per cent of the colony developed respiratory infections. These were divided into febrile and afebrile groups. This was possible since all febrile individuals with mouth temperatures of $99.6^{\circ} \mathrm{F}^{\mathbf{8}}$ or over were immediately removed from the houses and placed in bed in an excellent hospital on the colony grounds.

Amongst the febrile group the clinical picture was typical of that associated with epidemics of grippe or influenza with a low leukocyte count of

8 It was customary in the colony to hospitalize only those with temperatures considered significant, and for this reason the arbitrary figure of $99.6^{\circ} \mathrm{F}$. was established.
4000 to 7000 (unless secondary complications occurred), considerable backache, headache and aching in the muscles of the extremities, and certain signs and symptoms of upper and lower respiratory involvement. The afebrile group resembled more closely cases of common cold. There was some overlapping of signs and symptoms in the two groups. The epidemic was considered at an end when admissions to the hospital dropped to one every other day. Table II, showing the com-

TABLE II

Summary of clinical results

\begin{tabular}{|c|c|c|c|c|c|}
\hline \multirow{2}{*}{ Group } & \multirow{2}{*}{$\begin{array}{l}\text { Num- } \\
\text { ber in } \\
\text { group }\end{array}$} & \multicolumn{2}{|c|}{ Febrile cases } & \multicolumn{2}{|c|}{ Afebrile cases } \\
\hline & & $\mathrm{N}_{\text {ber }}$ & $\begin{array}{c}\text { Per } \\
\text { cent }\end{array} \mid$ & Num- & $\begin{array}{l}\begin{array}{c}\text { Per } \\
\text { cent }\end{array} \\
\text { con }\end{array}$ \\
\hline $\begin{array}{l}\text { Unvaccinated....... } \\
\text { S-15 vaccinated.... } \\
\text { PR-8 vaccinated... }\end{array}$ & $\begin{array}{l}550 \\
138 \\
110\end{array}$ & $\begin{array}{r}69 \\
17 \\
3\end{array}$ & $\begin{array}{r}12.5 \\
12.4 \\
2.7\end{array}$ & $\begin{array}{l}59 \\
20 \\
16\end{array}$ & $\begin{array}{l}10.7 \\
14.3 \\
14.5\end{array}$ \\
\hline
\end{tabular}

Application of the $\mathrm{X}^{2}$ test to these data shows that the observed differences in the febrile cases between the PR-8 vaccinated and the unvaccinated groups are significant. The above data differ slightly but not significantly from the preliminary report mentioned (24) owing to a more complete analysis of the case records than was possible at the end of the epidemic when the preliminary report was made.

parative incidence of febrile and afebrile cases in the vaccinated and the unvaccinated groups, includes only cases which occurred after the seventh day from the time of the first vaccination. Other studies have demonstrated the development of immunity during the second week following exposure to the virus (25). The essential point in Table II is the low incidence of the febrile disease in the group vaccinated with the human virus. In only one of the three febrile cases occurring in this group, a boy of 8 (F. C.), did the temperature rise to over $100^{\circ} \mathrm{F}$. This boy developed a temperature of $103^{\circ}$ and appeared to have typical influenza. That the low incidence might have been due to a nonspecific reaction from the emulsion injected is not probable, since the percentage incidence of the febrile disease in the group vaccinated with swine virus was equal to that of the unvaccinated group. In addition, it is evident that the incidence of afebrile infection in the three groups appears to be affected little if any by vaccination with either virus.

It appears probable that the afebrile groups in- 
cluded both the cases of common cold and the cases of mild influenza. On this account a reduction would have been expected in the incidence of afebrile cases amongst the group vaccinated with human virus. The absence of such a reduction may have been due to the fact that the vaccination shifted to the afebrile or mild group a number of cases who without vaccination would have been in the febrile group.

\section{Influenza virus as a probable causative agent in the epidemic}

At the height of the epidemic, washings were taken from the noses and throats of three unvaccinated individuals who were hospitalized and from two hospitalized individuals who had received swine virus vaccine. Since we were unable to obtain ferrets at this time, Dr. Francis kindly agreed to pool the washings from the vaccinated and unvaccinated groups respectively and to inject them into two ferrets at the Rockefeller Institute for Medical Research. One of the ferrets died of pneumococcal empyema and no influenza virus was obtained by passage from the other ferret.

It is also possible to determine the presence or absence of the influenza virus as a causative agent of such an epidemic by means of neutralization tests on the sera of unvaccinated individuals who suffered attacks of the disease (12). The serum was collected in the early stages of the disease and three weeks following the attack, and a comparison of the results of neutralization tests was made. Such determinations were made on the sera of a few of the unvaccinated hospitalized individuals in the colony and on the sera of a number of infants and children in the nearby city of Philadelphia who were attacked during the same epidemic and in a similar manner to those in the colony. Amongst the individuals in this entire group who showed no neutralizing antibodies in their serum at the height of the disease, there were found some who had them against the human virus, in a 1:1 mixture of the virus suspension and serum, following convalescence. In one child partial neutralization was found following convalescence, while in the other children there was complete neutralization. The evidence therefore is good that the human influenza virus was present during the epidemic; that it was the causative agent also appears probable. In the few cases studied which already possessed marked neutralizing properties in their sera, no increase or decrease of such antibodies was noted following convalescence, with the exception of one case which showed a moderate decrease.

The neutralization tests on the sera of these children are shown in Table III. As mentioned

TABLE III

Neutralization tests on sera taken at height of illness and during convalescence in the youngest group of cases from the epidemic area around the colony

\begin{tabular}{|c|c|c|c|c|c|c|}
\hline \multirow{2}{*}{ Case } & \multirow{2}{*}{ Age } & \multirow{2}{*}{$\begin{array}{l}\text { High- } \\
\text { est } \\
\text { tem- } \\
\text { pera- } \\
\text { ture }\end{array}$} & \multirow{2}{*}{$\begin{array}{c}\text { Days } \\
\text { in } \\
\text { hos- } \\
\text { pital }\end{array}$} & \multirow{2}{*}{$\begin{array}{c}\text { Days of } \\
\text { illness } \\
\text { previous } \\
\text { to first } \\
\text { test }\end{array}$} & \multicolumn{2}{|c|}{ Neutralization tests } \\
\hline & & & & & Date & Result \\
\hline T.H. & $\begin{array}{c}\text { years } \\
7\end{array}$ & $\begin{array}{l}{ }^{\circ} F . \\
104.0\end{array}$ & 13 & 3 & $\begin{array}{c}1996 \\
\text { March } 19\end{array}$ & Complete protection \\
\hline E.D. & 3 & 100.2 & 21 & 11 & $\begin{array}{l}\text { March } 18 \\
\text { April } 7\end{array}$ & $\begin{array}{l}\text { Complete protection } \\
\text { Partial protection }\end{array}$ \\
\hline W.B. & 2 & 103.8 & 70 & 17 & $\begin{array}{l}\text { March } 22 \\
\text { March } 30\end{array}$ & $\begin{array}{l}\text { Complete protection } \\
\text { Complete protection }\end{array}$ \\
\hline L.G. & 3 & 105.0 & 28 & 15 & $\begin{array}{l}\text { March } 26 \\
\text { April } 4\end{array}$ & $\begin{array}{l}\text { No protection } \\
\text { Incomplete protection }\end{array}$ \\
\hline J.J. & $1 \frac{1}{\mathbf{z}}$ & 105.0 & 13 & 7 & $\begin{array}{l}\text { March } 17 \\
\text { March } 21\end{array}$ & $\begin{array}{l}\text { No protection } \\
\text { No protection }\end{array}$ \\
\hline L.L. & 6 & 100.8 & 15 & 3 & $\begin{array}{l}\text { March } 18 \\
\text { April } 7\end{array}$ & $\begin{array}{l}\text { No protection } \\
\text { Complete protection }\end{array}$ \\
\hline J.P. & 4 & 99.8 & 4 & 12 & $\begin{array}{l}\text { March } 30 \\
\text { April } 4\end{array}$ & $\begin{array}{l}\text { No protection } \\
\text { Complete protection }\end{array}$ \\
\hline E.R. & 2 & 103.4 & 17 & 14 & $\begin{array}{l}\text { March 24 } \\
\text { April } 7\end{array}$ & $\begin{array}{l}\text { No protection } \\
\text { Complete protection }\end{array}$ \\
\hline E.S. & 5 & 105.6 & 16 & 21 & $\begin{array}{l}\text { March 30 } \\
\text { April 10 }\end{array}$ & $\begin{array}{l}\text { Complete protection } \\
\text { Complete protection }\end{array}$ \\
\hline
\end{tabular}

in this report and in the reports of other workers, neutralizing properties against the human virus are found in approximately 66 per cent of children at these ages (20). The fact that complete neutralization of the virus was found in a number of the cases during their illness may have been due to the length of illness before admission to the Hospital and therefore before the serum was withdrawn; all of the children were admitted on account of severe complications such as bronchopneumonia following mild upper respiratory disturbances of considerable duration. The length of their illness previous to the first withdrawal of serum for testing is shown also in Table III.

\section{DISCUSSION}

The epidemic described was of moderate severity. That it was considered as influenza from 
the clinical standpoint depended chiefly upon the low leukocyte counts and the respiratory symptoms together with aching of the limbs, head, and back. From the laboratory standpoint the appearance of neutralizing antibodies in the sera of unvaccinated children in the epidemic area around the colony during convalescence when none were present in their sera during the illness, places the human influenza virus in all probability as the causative agent. The low incidence of the epidemic disease in the group of individuals vaccinated with the active human influenza virus corroborates the clinical and laboratory evidence. Studies of the nasal and throat washings were not sufficient to furnish significant data.

It is of interest that a large group of individuals who possessed neutralizing properties against the virus of human influenza should still be susceptible to the disease, if the human virus was the causative agent. The findings of Smith, Andrewes, and Laidlaw (8) that ferrets with waning immunity may be infected while still showing neutralizing antibodies in their sera may explain this susceptibility. In addition, it is of interest that vaccination of a large group of individuals with active human influenza virus increased the serum neutralizing antibodies in only 31 per cent, and yet appeared to increase the resistance to infection in practically the entire group injected. That immunity and neutralizing properties are associated but do not in many instances run parallel to each other has been well demonstrated by Shope in his studies of swine influenza virus. However, when such neutralizing antibodies appear for the first time in an individual's serum during convalescence from an infection, the influenza virus in all probability is the responsible factor.

\section{SUMMARY AND CONCLUSIONS}

1. The neutralizing properties of human sera collected from individuals of different age groups, against the viruses of human and swine influenza are tabulated and compared with the results of other workers.

2. The intramuscular vaccination with active swine and human influenza virus of a group of individuals in a large State Colony, in the presence of an oncoming epidemic of "influenza," is described. One hundred and ten individuals were vaccinated with human virus and 138 individuals with swine virus, while 550 were not vaccinated.

3. The incidence of febrile and afebrile infection in the colony is tabulated. There was an incidence of 2.7 per cent febrile cases in the group vaccinated with human virus as compared with an incidence of approximately 12.5 per cent in the other two groups. This difference is statistically significant. In a comparison of the incidence of the afebrile, the " common cold" type of infection, in the three groups no significant difference was noted.

4. The presence of the human influenza virus during the epidemic as a probable causative agent was determined by means of neutralization tests on the serum of a number of hospitalized children in the epidemic area who had not been vaccinated. During the height of their illness no neutralizing antibodies against the human virus were found, whereas during convalescence they appeared for the first time. Studies of the nasal and throat washings from the febrile cases were not sufficient to furnish significant data.

5. Additional evidence is furnished suggesting that resistance to infection and neutralizing properties of serum are associated but probably do not always parallel each other.

6. Further studies of a similar nature among larger groups of individuals will be necessary before final conclusions can be drawn concerning the value of immunization against influenza with the active human influenza virus.

\section{BIBLIOGRAPHY}

1. Shope, R. E., Swine influenza. I. Experimental transmission and pathology. J. Exper. Med., 1931, 54, 349

2. Lewis, P. A., and Shope, R. E., Swine influenza. II. A hemophilic bacillus from the respiratory tract of infected swine. J. Exper. Med., 1931, 54, 361.

3. Shope, R. E., Swine influenza. III. Filtration experiments and etiology. J. Exper. Med., 1931, 54, 373

4. Shope, R. E., Studies on immunity to swine influenza. J. Exper. Med., 1932, 56, 575.

5. Smith, W., Andrewes, C. H., and Laidlaw, P. P., A virus obtained from influenza patients. Lancet, 1933, 2, 66.

6. Andrewes, C. H., Laidlaw, P. P., and Smith, W., The susceptibility of mice to the viruses of human and swine influenza. Lancet, 1934, 2, 859. 
7. Laidlaw, P. P., Epidemic influenza: A virus disease. Lancet, 1935, 1, 1118.

8. Smith, W., Andrewes, C. H., and Laidlaw, P. P., Influenza: Experiments on the immunization of ferrets and mice. Brit. J. Exper. Path., 1935, 16, 291.

9. Andrewes, C. H., Laidlaw, P. P., and Smith, W., Influenza: Observations on the recovery of virus from man and on the antibody content of human sera. Brit. J. Exper. Path., 1935, 16, 566.

10. Francis, T., Jr., Transmission of influenza by filtrable virus. Science, 1934, 80, 457.

11. Shope, R. E., Infection of ferrets with swine influenza virus. J. Exper. Med., 1934, 60, 49.

12. Francis, T., Jr., and Magill, T. P., Immunological studies with virus of influenza. J. Exper. Med., 1935, 62, 505.

13. Shope, R. E., The infection of mice with swine influenza virus. J. Exper. Med., 1935, 62, 561.

14. Francis, T., Jr., Immunological relationships of strains of filtrable virus recovered from cases of human influenza Proc. Soc. Exper. Biol. and Med., 1935, 32, 1172.

15. Francis, T., Jr., and Shope, R. E., Neutralization tests with sera of convalescent or immunized animals and the viruses of human and swine influenza. J. Exper. Med., 1936, 63, 645.

16. Francis, T., Jr., Studies in influenza. Pennsylvania M. J., 1937, 40, 249.
17. Burnet, F. M., Influenza virus isolated from Australian epidemic. M. J. Australia, 1935, 2, 651.

18. Francis, T., Jr., Recent advances in the study of influenza. J. A. M. A., 1935, 105, 251.

19. Francis, T., Jr., and Magill, T. P., Vaccination of human subjects with virus of human influenza. Proc. Soc. Exper. Biol. and Med., 1936, 33, 604.

20. Francis, T., Jr., and Magill, T. P., The incidence of neutralizing antibodies for human influenza virus in the serum of human individuals of different ages. J. Exper. Med., 1936, 63, 655.

21. Shope, R. E., The incidence of neutralizing antibodies for swine influenza virus in the sera of human beings of different ages. J. Exper. Med., 1936, 63, 669.

22. Armstrong, C., and Lillie, R. D., Experimental lymphocytic choriomeningitis of monkeys and mice produced by a virus encountered in studies of the 1933 St. Louis encephalitis epidemic. Pub. Health Rep., 1934, 49, 1019.

23. Rivers, T. M., and Scott, T. F. M., Meningitis in man caused by a filtrable virus. Science, 1935, 81, 439.

24. Chenoweth, A. D., Waltz, A. D., Stokes, J., Jr., and Gladen, R. G., Active immunization with the viruses of human and swine influenza. Am. J. Dis. Child. (Proc.), 1936, 52, 757.

25. Francis, T., Jr., and Magill, T. P., J. Exper. Med. (In press.) 